will give value. One man can pack and operate it. The reliable little engine plugs along without attention. If a change of hose is needed or another length to be added the stream is stopped by simply lifting the suction out of the supply without danger of burning out the motor or delay in restarting.

Delivery of water in the experimental model is about 10 gallons per minute at $65 \mathrm{lbs}$ pressure through 5/16-inch nozzle. A 63-foot stream through a $1 / 4$ inch nozzle is obtained through 1,000 feet of $11 / 2$-inch linen hose with an elevation of about 25 feet.

Those are the only figures Jim MacDonald will quote on performance. $\mathrm{He}$ is content that he gets a fair stream and can now quote experience of rangers and other fire fighters who have used experimental models that this little gadget finds many a useful spot where other pumps would not or could not be used.

And finally-economy. The units are cheap to build compared to present standard pumpers. The comparison must, of course, be local, but experience indicates a proportion of at least 2 to 1 and maybe 3 to 1 .

The British Columbia Forest Service has now had a dozen units built for field use next year. It is possible that it can be improved, but only use on the fire-line will tell.

\title{
SAWMILL MAP OF CANADA
}

A SAWMILL map of Canada has just been published by the Dominion Forest Service. The map has been issued in two sheets on a scale of 35 miles to the inch. Each is complete in itself, one covering the Maritimes, Quebec, and Ontario, and the other taking in the Prairie Provinces and British Columbia. Over 6,600 mills have been plotted in their correct locations in accordance with information furnished by the provinces at the end of 1940 . Each mill has been placed in one of six classes rated on a basis of annual production, and the class to which a mill belongs is indicated on the map by one of the six symbols used. The lowest class includes mills cutting less than 1 million board feet of lumber annually, and the highest comprises those mills cutting more than 20 million board feet.

To accompany the map sheets, lists have been prepared for each province containing the names of owners in alphabetical order, followed by mill locations and post office addresses and, wherever the information was available, the species cut and the products other than lumber are also given. The lists for the four western provinces are bound in one cover, and those for the five eastern provinces in another.

Copies of the maps and lists may be obtained from the Dominion For. ester, Ottawa, at a cost of 50 cents per sheet accompanied by list, for either the Eastern or Western maps, or both sheets with the two lists for $\$ 1.00$. Remittances should be made payable to the Receiver General of Canada. 